\title{
Top-Down Self-Organization: State Logics, Substitutional Delegation, and Private Governance in Russia
}

\author{
MASHA HEDBERG*
}

\begin{abstract}
This study investigates the counterintuitive emergence of self-regulation in the Russian construction sector. Despite its proclivity for centralizing political authority, the government acted as the catalyst for the delegation of regulatory powers to private industry groups. The article argues that a factor little considered in extant literature-namely, a weak and corrupt bureaucracy - is key to explaining why the normally control-oriented executive branch began to promote private governance despite industry's preference for continued state regulation. The article's signal contribution is to theoretically explain and empirically demonstrate how a government's prior inability to establish intrastate control over an ineffective and bribable public bureaucracy creates incentives for political authorities to search for alternative means for policy implementation outside of existing state agencies. These findings are important for understanding the impetus and logic behind particular regulatory shifts in countries where the state apparatus is both deficient and corrupt.
\end{abstract}

\section{Introduction}

Intriguing changes to the regulatory regime governing the Russian construction sector were introduced in January 2010. Championed by the presidential administration and its allies in the State Duma, the new regulatory framework stripped a long-established agency of the prerogative to regulate the sector through state licensing, and instead entrusted oversight responsibility to private industry associations. Despite its proclivity for centralizing political authority, the government not only condoned but instigated the delegation of regulatory power to industry. But rather than welcoming the prospect of self-governance, Russian construction companies, both large and small, persistently and vocally resisted the regulatory change. This perplexing constellation of actors for and against private governance warrants careful attention. Why did the normally control-oriented regime choose to devolve regulatory power onto the private sector? Why did the industry have to be coaxed and cajoled into accepting self-regulation ${ }^{1}$

This article argues that the Russian government's prior inability to establish effective intrastate control over an ineffective and corrupt public bureaucracy created incentives for political executives to search for alternative means for policy implementation outside of existing state agencies. I thus suggest that governments delegate public functions to private agents in order to compensate for the state's own regulatory incapacity. I term this substitutional delegation. By demonstrating why and how bureaucratic subversion affects the government's decision to delegate regulatory responsibility to private actors, the argument identifies factors that shape state decision making that go underexplored within existing literature.

*European University Institute and Johns Hopkins University (SAIS Europe)

Governance: An International Journal of Policy, Administration, and Institutions, Vol. 29, No. 1, January 2016 (pp. 67-83).

(C) 2015 Wiley Periodicals, Inc.

doi:10.1111/gove.12140 
While some of the literature on state capacity has demonstrated how governments cultivate external linkages in order to facilitate capacity (Doner 1992; Evans 1995; Lucas 1997; Maxfield and Schneider 1997), the relationship between the state's preexisting regulatory capacity and the "outsourcing" of regulatory authority has not been adequately brought into debates on delegation to private actors. Rather, extant theories view the government's decision to devolve public functions to private industry groups as a response to business preferences or pressure (Kay 1988), or as a means to complement the public sector with superior private sector expertise (Grajzl and Murrell 2007; Héritier and Eckert 2008; Mattli and Büthe 2005), or as a byproduct of competition between rival state agencies (Frye 2000). While generating useful insights into delegation across a number of contexts, conventional explanations tend to neglect a salient feature of many polities: low capacity bureaucracies that severely curtail the government's ability to enact its policy agenda. The challenge, therefore, is to develop a theory that takes into account this pernicious governance problem, thus better elucidating the impetus behind particular regulatory shifts in countries where the state apparatus is both deficient and corrupt.

While privileging the question of state motivations, this article also addresses the second puzzle: Why did industry resist? Corruption in the public sector also factors into firms' calculations of whether or not to support industry self-regulation. For many Russian construction firms, the state licensing regime was strict only on paper. In practice, few firms were punished for failing to comply with regulatory mandates. As a result, firms viewed self-regulation as the stricter and more costly alternative to continued regulation by corruptible regulators. When the "shadow of hierarchy" - the threat of direct government intervention — can be attenuated through resort to informal ties, as well as outright bribes, there are fewer incentives for firms to embrace self-governance.

The article proceeds in five parts. Part I reviews existing explanations for delegation to industry and highlights the literature's shortcomings in dealing with states with weak regulatory capacity. Part II elaborates on what I term substitutional delegation. Part III provides the case study. The research brings together interviews with firms, business associations, and government officials that I conducted in Russia in 2008 and 2010, as well as an extensive examination of the available primary sources. ${ }^{2}$ Part IV evaluates the argument against alternative explanations in light of the empirical record. The conclusion in Part V discusses avenues for further research.

\section{Government Actors, Private Agents, and Delegation}

By drawing out the relationship between the government's decision to cede regulatory authority and the state's preexisting regulatory capacity, the argument seeks to augment the existing literature that either neglects the salience of bureaucratic capacity or assumes a high-functioning regulatory state. The rest of the section reviews the three prevailing, and rather disparate, types of explanations for why governments delegate to private actors, highlighting the lacunae that remain when it comes to states with weak regulatory capacity.

Research on industry self-regulation has documented myriad cases of private governance across diverse economic sectors, particularly in advanced industrial democracies. The bulk of the work, however, has focused on understanding why industry engages in self-regulation and the conditions under which private governance regimes are likely to prove more (in)effective. Significantly less has been written on why governments opt to put regulatory responsibility into the private sector's hands. Scholars broaching this related, but analytically distinct, question often posit that 
governments do so in order to benefit from the superior expertise and technical knowledge possessed by industry when developing policy. ${ }^{3}$ Empirically, what might be called "expertise-driven" motivations for delegation have been found to be particularly common in highly technical and complex issue areas, such as environmental policy (Héritier and Eckert 2008) and accounting (Mattli and Büthe 2005), as well as in markets that exhibit fast-changing dynamics (Stefanadis 2003).

The government's logic here is largely one of time and cost constraints. As Mattli and Büthe (2005) note, in "highly technical, complex issue areas, governments are likely to find the requisite expertise more costly to acquire and maintain than private actors-especially if maintaining expertise requires keeping up with the latest developments in a fast-changing technology" (402). The government's objective is thus to complement public policymaking with input from the more expert private sector. State actors would prefer to legislate rather than delegate (see, e.g., Héritier and Eckert 2008, 115), as well as have more trust in public servants over market actors, but the time and costs involved in building up "in-house" expertise weigh in favor of delegation.

The public-interest motivations for delegation implied in these accounts may, of course, find detractors. From the perspective of private interest or capture theory, self-regulation, like other forms of regulation, ought to arise from industry preferences and pressure on public officials, rather than the government's attempt to govern better and more frugally (Becker 1983; Posner 1974; Stigler 1971). To quote Stigler's (1971) famous maxim: "As a rule, regulation is acquired by the industry and is designed and operated primarily for its benefit" (3). Along this line of reasoning, self-regulation should be sought by firms, since it can obviate the costly and time-consuming task of exerting direct influence on state officials or institutions. As Kay (1988) notes, "with self-regulation, regulatory capture is there from the outset" (34). Government actors, for their part, are driven to devolve regulatory authority or extend the use of selfregulation because there is much to be gained from satisfying well-organized interest groups, a vital source of electoral and financial support (Ogus 1999; Trebilcock 1983).

Moving beyond both the expertise-driven and interest-group-driven approaches, Frye (2000) posits another logic. Examining the formation of self-governing organizations in the Russian financial sector in the turbulent early 1990s, Frye finds that state agencies that faced intense competition from rival organizations strongly backed extensive delegation to private actors. He theorizes that threats from "rivals within the state" prompt bureaucrats to seek outside alliances in order to secure their position vis-à-vis opponents. By delegating authority to market participants, who Frye posits "typically prefer self-governance," bureaucrats can build a loyal and grateful clientele, which can "serve as important allies in struggles against bureaucratic rivals" (168).

\section{Regulatory (In)Capacity: The Missing Variable}

While the expertise-driven, interest-group-driven, and competition-driven explanations have much enriched our understanding of delegation, they each in their own way take regulatory capacity as a given, rather than an object of analysis. They thus might miss the impetus and logic underpinning the devolution of regulatory authority to agents outside the existing apparatus.

Expertise-driven explanations are largely derived from studies of delegation in advanced industrial democracies, predominantly the United States and Western Europe. As a result, they can take for granted that policymaking is backed by something akin to a "Weberian" bureaucracy-a highly professionalized cadre of honest public servants that can be relied upon to carry out the policy goals set by the political 
leadership. Hence the literature's focus on the input side of the policymaking process and the concomitant stress on technical knowledge or "expertise."

However, as a bleak empirical record shows, the bureaucratic apparatus in many countries strays far from any ideal. Public agencies frequently are understaffed and underfunded. Meritocratic recruitment may well be absent, as can a professional esprit de corps. Corruption can be rampant and create strong incentives for public servants to work for personal gain rather than implement the goals laid out in state policy. Alone or in combination, such factors can vitiate the bureaucracy's role as an effective instrument for carrying out state policies.

The problem for political executives in such contexts is not just how to bolster the expertise of an otherwise well-functioning bureaucracy. ${ }^{4}$ The challenge is much more vast: how to generate desired policy outcomes in bureaucratic environments that hinder policy implementation from within. To overlook this crucial difference between low- and high-capacity bureaucracies runs the risk of yielding only a partial understanding of the logic underpinning the devolution of regulatory authority to agents outside the existing public apparatus. Put alternatively, while expertise-driven explanations correctly view delegation as serving to supplement some public sector deficit (i.e., insufficient technical expertise), by omitting consideration of implementation capacity they provide a highly incomplete account of the public sector deficiencies that need to be addressed.

But interest-group-driven and competition-driven theories, too, underplay the salience of state capacity, though in a different way. An essential premise of these arguments is that firms prefer self-regulation over government regulation. This characterization, however, warrants more scrutiny in contexts where the state apparatus is weak. There is considerable evidence that it is largely fear of stricter government action-the "shadow of hierarchy"-that drives most self-regulatory initiatives (Gunningham and Rees 1997; Halfteck 2008; Héritier 2003; Segerson and Miceli 1998). That is, firms prefer private governance because it can ward off more stringent state regulation (Maxwell, Lyon, and Hackett 2000). This too, however, hinges on the presence of a regulatory state that is strong in a particular sense: It is backed by conscientious and incorruptible public agents which make credible the threat of strict enforcement.

An incapacitated bureaucracy, however, significantly enfeebles the credibility of enforcement, and hence the fear of more stringent legislation. When the "shadow of hierarchy" can be attenuated through resort to informal ties, as well as outright bribes, firms may not prefer self-regulation over continued oversight by ineffective or corruptible regulators. In other words, firm preferences themselves may be contingent on the degree of bureaucratic subversion, and may need to be empirically established, rather than a priori assumed.

There thus are strong grounds to expect that the dynamics surrounding delegation are distinctly different when the state's regulatory capacity is weak or debilitated, even as extant approaches remain silent on this issue. As a result, theoretical explanations may need to be more attuned to how bureaucratic subversion alters and shapes state decision making with respect to delegation to private actors. The next section develops this intuition further.

\section{Substitutional Delegation: Toward a Theory}

I argue that the government's prior inability to establish effective intrastate control over an insubordinate and corrupt public bureaucracy creates incentives for political authorities to search for extrastate substitutes for existing state agencies. Governments 
delegate public functions to private agents in order to compensate for the state's own regulatory incapacity and circumvent a recalcitrant bureaucracy. I term this substitutional delegation.

The argument starts with the assumption that political executives, the actors atop the political hierarchy, are, as a rule, concerned with enacting their economic agenda, whether because honoring policy promises bolsters electoral prospects, or in the absence of strong electoral pressures, because economic development is an important basis upon which rule is legitimated (see, e.g., White 1986).

Agenda fulfillment, however, hinges on bureaucratic performance and compliance with clearly articulated state goals. An institutionally debilitated state apparatus can thus itself become an internal obstacle to the political leadership's policy ambitions. A vivid illustration of this can be found in U.S. diplomatic cables, made public through Wikileaks, that report that "while Mr. Putin enjoys supremacy over all other public figures in Russia, he is undermined by an unmanageable bureaucracy that often ignores his edicts" (Shane and Lehren 2010).

One possible solution to this governance challenge is public sector reform. Yet as all too frequently found, this strategy is fraught with difficulties. Capacity-enhancing administrative reform demands not only an infusion of resources and major investment in human capital, but the cardinal transformation of the entrenched incentives structures that breed corruption. It also requires institutionalization, which means maintaining the reform impulse over long periods of time even in the face of stiff internal resistance (Schneider and Heredia 2003).

Put simply, reliable bureaucratic performance cannot be bought cheaply or acquired easily. Yet, the imperative to enhance the governance of particular economic sectors remains and can become especially acute when times of economic crisis or increased economic activism on the part of the state render particular industrial sectors more fiscally or politically important.

When the economic policy goals of the political leadership are poorly furthered, or even directly undermined, by its existing public agents, circumvention can become a particularly appealing, and politically expedient, strategy. From the government's perspective, delegation of regulatory responsibility to the private sector enables the substitution of a malfunctioning state bureaucracy in all three stages of the regulatory process-standard setting, monitoring, and enforcement.

As suggested by other accounts, delegation helps bolster policy measures with private sector expertise. As private firms command greater knowledge about the industry, their superior expertise may be expected to lower the information costs for developing new policies or modernizing regulatory standards (Stefanadis 2003). More importantly, however, the reassignment of regulatory authority can address the "output" aspects of incapacity, inadequate monitoring, and enforcement by public agents. In this case, mandating self-regulation by industry is plausibly the less costly alternative to continued reliance on a rapacious bureaucracy. As some economics literature suggests, the "optimal use of [an] alternative supplier involves calling upon his services when the actual or predicted performance of the incumbent is particularly poor" (Demski, Sappington, and Spiller 1987; Nalebuff and Stiglitz 1983; Sappington 1991).

Relative to administrative reform, self-regulating organizations within the private sector can be created with speed. Thus the "outsourcing" of regulatory responsibilities to private industry groups provides a swift way for political authorities to alter incentives facing both industry players and bureaucrats, and to do so in ways that tend to be self-enforcing. By contrast, the logic of administrative reform is different: Strategies employed to alter the incentives facing bureaucrats do not tend to be self-enforcing, 
leaving unaltered the political principals' need to spend time and energy directly monitoring bureaucrats to ensure that reforms stick (Schneider and Heredia 2003).

Substitutional delegation also serves to diminish bureaucratic discretion and reduce the scope of opportunities for graft within the sector in which industry self-regulation is enacted. As studies of congressional delegation suggest, political principals are frequently drawn to constrain bureaucratic autonomy when bureaucrats' preferences diverge from those of legislators (Epstein and O'Halloran 1996; Lewis 2003). Corruption within the public sector, in this sense, should be viewed as a particularly severe case of misalignment of interests between political principals seeking to enact an economic agenda and self-regarding public agents seeking private gain. Endemic, as opposed to localized, corruption also renders traditional mechanisms that enable principals to monitor agents or to establish incentive schemes that better align agents' interests considerably more costly to undertake than in national settings with less subversion.

The top-down fostering of private industry groups may also create an additional mechanism through which to monitor and discipline wayward public servants. As Markus (2007) shows, the Putin administration began to involve three peak-level business associations in the policymaking process in order to exert pressure on a recalcitrant bureaucracy. Similarly, Lucas (1997) argues that mobilized business associations can "act as a force for disciplining the state in limited areas" (74). This also is consistent with studies showing that interest groups serve as "fire alarms" that alert policymakers to bureaucratic transgressions (Epstein and O'Halloran 1995; Hopenhayn and Lohmann 1996; McCubbins and Schwartz 1984). Notably, however, the argument made here goes beyond these works by suggesting that rather than simply "authorize" existing groups, the government itself initiates the formation of de novo groups that can act as substitutes for underperforming bureaucracies. ${ }^{5}$

To be clear, the ultimate success of a substitutional strategy likely depends on whether firms respond favorably. Fortunately or unfortunately, political authorities are neither omniscient nor infallible. Policymakers can decide to devolve authority to industry, but then make poor choices with respect to institutional design, the proper mix of positive and negative incentives that promote "responsible self-rule." ${ }^{6}$ That is, failure may ensue irrespective of government intentions. The question of the ex post conditions for successful outcomes, however, is analytically separate from the question of ex ante motivations that the present research seeks to address.

The next section provides a case study to probe the initial plausibility of the new analytical lens being proposed. Notwithstanding the limitations of a single case, the advent of industry self-regulation in the Russian construction sector provides sufficient evidence both to test the link between the logic of the theory and observed behavior, and to compare the argument against several alternative explanations that could be advanced to account for the government's decision to devolve regulatory power onto the private sector.

\section{The Imperative to Rebuild Russia}

Over the past decade, the Putin and Medvedev administrations have sought to enact an ambitious modernization plan for Russia, with new construction as a key building block in the Russian Development Strategy for 2020. As one government official aptly put, "All modern long-term state programs in Russia these days have a decidedly clear 'building hue."7 The grandest projects involved preparations for the 2012 APEC Summit in Vladivostok, the 2013 Universiade in Kazan, and the 2014 Winter Olympics in Sochi. The federal budget for 2011-2013 allocated \$17.5 billion for the Sochi projects 
alone. As numerous observers have noted, "The Sochi Games, in many respects, reflect a personal ambition of President Putin, the most audacious in a series of megaprojects that illustrate the nation's rise from post-Soviet chaos under his leadership" (Herszenhorn 2014).

Less visible, but no less a priority, has been residential construction, which in 2008 Putin designated a "strategic state objective" (RIA Novosti September 23, 2008). The national project "Accessible Housing" initially aimed to double the annual rate of housing construction to 80 million square meters. Unwilling to settle for a mere 80 million, then-president-to-be Medvedev upped the ante at the 2007 Presidential Council for Priority National Projects, promising 100-130 million square meters a year. The program "Public Health," meanwhile, called for the building of modern medical centers throughout Russia. Further initiatives sought to develop new economicindustrial zones across the country. The 2008 economic crisis augmented the government's role in the construction market. As summed up by one industry report: "As the flow of private investment into construction activity became markedly weaker, statefunded projects began to account for a more substantial proportion of construction activity" (PMR Publications 2010).

The country's decaying infrastructure also attracted the government's notice. In 2005, the Emergency Situations Ministry warned that aging Soviet-era infrastructure would be a major factor in industrial accidents. The public outcry following the deadly accidents at Moscow's Transvaal amusement park in 2004 and the Basmanny market in 2006, when buildings earlier found safe by state inspectors unexpectedly collapsed, transformed these concerns into politically salient issues. "Russia's infrastructure requires urgent attention and in many cases is in need of immediate modernization," then-President Medvedev said following another devastating accident, this time at the Sayano-Shushenskaya dam in 2009 (Smolchenko 2009).

But even as construction grew in both political and economic importance, the industry remained riddled with problems, many of which were attributed to a debilitated and insubordinate bureaucracy. For example, the 2002 Law on Technical Regulation (N 184-\$3) sought the revision and upgrade of some 500,000 GOSTs, relics of the command economy, to meet the demands of the twenty-first-century post-Soviet market. Yet, as noted in the 2005 report by the Expert Advisory Council on Construction, Architecture and the Construction Industry, "At present, not one single draft technical regulation [for the construction industry] has been submitted for review ... even though the federal budget earmarked funds." Such breakdowns in the chain of command are common (see, e.g., Monaghan 2012). According to one estimate, "over 1800 of Putin's presidential decrees and instructions (excluding appointments) had not been implemented by the time he left office in 2008" (Sakwa 2010, 32). As Medvedev publically bemoaned: "In order to meet deadlines, our dear colleagues report that such and such has been done. However, in reality-when a case is examined-it reveals that nothing was done" (RIA Novosti March 16, 2010).

Official sources, both publically and privately, concede the leadership's limited ability to ensure its economic agenda is followed through on by the state apparatus, often acknowledging that the "deprofessionalization" of the bureaucracy is compounded, if not bred, by rampant corruption. ${ }^{8}$ In his November 2009 message to parliament, Medvedev went so far as to call "the state bureaucracy . . . a completely ineffective system [that] leads only to corruption."

Indicators show that the state-licensing and state-inspection regimes have been among the weakest and most corrupt areas within public administration. Data from the EBRD-World Bank Business Environment and Enterprise Performance Survey (BEEPS) reveal that in 2005 over $28 \%$ of Russian firms reported having to make 
"unofficial payments" in order to obtain "business licenses and permits," a sizable increase from the approximately $20 \%$ of firms who divulged doing so in 2002 . Notably, corruption in this sphere has only grown from year to year: The 2009 BEEPS found that close to $40 \%$ of firms in Russia were "expected to give gifts to get a construction permit."

In this respect, the construction sector epitomizes the dilemmas of a state with weak regulatory capacity. In 2007 alone, the Federal Agency of Construction, Housing and Housing Services (Rosstroi), the industry's chief regulator, issued over 75,000 licenses, rejecting only 282 applications. During that time, it forwarded a mere 172 complaints to arbitrage courts. Unless one is willing to believe that few Russian construction firms and building projects fail to meet any quality or safety standards, these numbers strongly suggest pervasive deficiencies in the oversight capacity of industry watchdogs, as well as the distinct possibility that the actions of public agents are motivated by private gain.

Commenting on the state of industry oversight, Viktor Pleskachevsky, a member of the ruling United Russia Party and Chairman of the State Property Committee, ascribed the problem to the fact that "control over the construction sector was being mechanistically carried out by the federal licencing center, which, for money, issued licences to any company that met the minimum formal requirements" (Zaslavskaya 2010). As Pleskachevsky noted elsewhere, whereas 15 agencies and 13 supervisory bodies at the federal, regional, and municipal levels technically oversee the industry, "buildings crumble, construction cranes fall ... [and] bridges collapse ... while the guilty have learned to evade responsibility" (Bryanskii 2007).

Thus viewed, the Russian construction industry exemplifies the governance challenge that can confront even the most politically powerful governments. Even as the industry became an investment priority for the presidential administration, with the state infusing billions into building projects and facing the looming prospect that the 2014 Winter Olympics would shine the international spotlight on Russian construction, government authorities were unable to alter and improve the performance of the public agencies in charge. As such, the case presents a prime arena for investigating a government's search for regulatory strategies that address the obstacles posed by a weak and corrupt state bureaucracy.

\section{From Attempts at Reform to Circumvention}

Escalating frustration with the public apparatus has over the years led the Russian executive branch to initiate a series of reforms that, on the one hand, sought to professionalize the civil service and, on the other, rein in opportunities for corruption. Such efforts have ranged from the application of positive and negative incentives to bureaucratic downsizing. Some attempts were made to increase the salaries of civil servants, as well as refine recruitment procedures. In order to reduce the scope of bureaucratic influence, several laws from 2001 to 2004, for example, sought to simplify the process of registering a new business (Yakovlev and Zhuravskaya 2008). The record suggests that these efforts proved largely inadequate (see, e.g., Huskey 2012; Milov et al. 2011).

Against this backdrop, the Ministry of Economic Development and the State Property Committee, with strong backing from the presidential administration, ${ }^{9}$ began advocating a more novel regulatory approach that called for the elimination of state licensing in several industries, first and foremost construction. In 2008, Rosstroi was unceremoniously abolished by presidential decree (May 12, 2008) and folded into the Ministry of Regional Development. Shortly thereafter, Prime Minister Putin signed off 
on amendments to Federal Law N 128- $\$ 3$ "On the Licensing of Individual Types of Business Activity," which designated January 2010 as the date when self-regulation would be introduced in the construction industry.

The new regulatory framework replaced the previous state-licensing approach with a private certification regime relying on self-regulating organizations (SROs). Instead of applying for a state license, construction firms apply for membership in an SRO, which then issues compliance certificates to previously vetted members allowing them to perform accredited activities. SRO membership was required for firms performing work deemed to affect "construction safety." ${ }^{10}$ Before an SRO could begin certifying its members, it itself needed to be approved by and registered with the Federal Service for Environmental, Technological and Nuclear Supervision (Rostekhnadzor).

The delegation of authority involved SROs in all three stages of the regulatory process: They were tasked with drafting guidelines for the industry segment they represented, vetting applicants in light of admission requirements, as well as monitoring member conduct through periodic inspections. If a member firm failed to comply with either the SRO's internal standards or existing legal and regulatory requirements, SROs were empowered to impose penalties, including the suspension and termination of certification. In order to ensure that SROs had the incentive to monitor industry, SROs were made financially liable for misconduct by member firms. Each SRO had to set up a pooled compensation fund to secure secondary liability, so that compensation for damages caused by a firm could be claimed from the SRO to which it belonged. To be certified as an SRO in the construction sector, an organization needed at least 100 members and a compensation fund of no less than 1 million rubles (c. $\$ 35,000)$ per member. The law enabling self-regulation also provided for the nonjudicial resolution of corporate disputes through peer courts (treteiskie sudy), as well as allowed firms to appeal against the actions of an SRO in arbitrage court, though only in the event of decertification.

\section{Why Delegate? Evaluating Alternative Explanations}

Why did the normally control-oriented Putin government decide to abandon the traditional "command-and-control" approach and turn to a novel strategy of regulating the sector through private governance? Several alternative explanations can be advanced to account for the government's actions.

First, it may be argued that delegation was driven by interest group pressure. Yet, when asked whether the construction industry would rejoice at the introduction of self-regulation, then Minister of Economic Development and Trade Elvira Nabiullina admitted that "thus far, it hasn't displayed sufficient activism in this respect" (Sokolova 2008).

Extensive interviews with firms in fact reveal meager interest in self-governance. "We are wary, to say the least," said one senior manager of a large Moscow-based construction company. "Even if self-regulation might have benefits in principle, I have reservations about how it will work in practice in a country like Russia," offered the CEO of a St. Petersburg builder of residential housing. ${ }^{11}$ As noted by one industry publication, "[Construction] market participations, curiously enough, support Rosstroi, even though for them the abolition of licenses, in principle, should simplify doing business" (Tofanuk 2004). Instead of asking for less government intervention, firms were demanding either the status quo or an even more powerful government body to oversee the industry. As the law on self-regulation was being debated in parliament, a consortium of business associations sent an open letter to President Medvedev and Prime Minister Putin, writing: 
They say that the market will solve all problems. But ... [t]he present fragmentation of the industry creates numerous problems in meeting the objectives you've set. We believe that ... self-regulating organizations will not help the situation. ... The Russian construction industry is not ready to master the SRO system, particularly given the current economic crisis. In general, it must be said that construction in such a huge country cannot successfully function without an industry headquarters that coordinates all actions, without the necessary supervision over activities. ... You absolutely correctly call construction a key industry. For the industry to be able to consistently meet the economic and social development needs of the country, it needs an industry headquarters, namely, a ministry of construction. (Stroitel'naya Gazeta November 21, (2008)

Self-regulation was perceived as not benefiting the industry for a variety of reasons. First and foremost, it upped costs in the form of membership dues and payments into the compensation fund. Firms also feared that industry self-regulation could spawn informal mechanisms enabling larger players to exclude smaller rivals. ${ }^{12}$ "Some members are concerned that if standards and rules [are] set by bigger companies, smaller firms will be unable to meet them and will be forced off the market," said Aleksei Kozhevnikov, Vice President of OPORA Russia, a business association representing small and medium-sized firms. But self-regulation sat equally uneasily with many large firms, according to representatives of the Russian Union of Builders. ${ }^{13}$ While these could absorb the additional costs, the possibility of exclusion from regional markets, as well as the uncertainty surrounding how the new system would work, weighed heavily on even the industry behemoths.

Evidence also suggests that industry was not strongly opposed to state oversight because regulatory agencies, like the abolished Rosstroi, had already been "captured." This intuition gains additional support considering that construction companies vocally backed Rosstroi as it fought to preserve its functions and prerogatives.

As the president of one large construction conglomerate offered in an interview: "We always prefer to deal with the devil we know. ... We know how to comply with [Rosstroi's] requirements when needed. We also know how to avoid compliance. ... . [But] this [self-regulation] ultimately is not about making us [construction companies] better. Our bureaucrats finally got too greedy for the higher ups, and at the wrong time, so now it's time to apply the stick."14

It thus seems hardly the case that the government delegated regulatory authority in order to satisfy an interest group. This is not to say that large construction firms may not derive benefits from the new regulatory regime. But while they may benefit more relative to smaller firms, it does not follow that the changes were enacted at their behest. $^{15}$

The empirical record is also not consistent with the competition-driven theory articulated by Frye (2000). Like the interest-group approach, it cannot explain the actual constellation of actors for and against industry self-regulation. If competition from rival agencies drives bureaucrats to support delegation to industry, then we would expect Rosstroi, the most embattled state agency, to vocally back self-regulation. Rosstroi, however, tenaciously fought to preserve state licensing. ${ }^{16}$ In some respects, its stance is not surprising: Given the industry's ambivalence toward self-regulation, the ally-building strategy described by Frye was not in the cards. Thus while bureaucratic rivalries may help explain delegation when industry prefers self-governance, this explanation fares less well when industry does not.

Finally, it might be argued that delegation was driven by the government's desire to avoid blame for future negative outcomes (Fiorina 1982), such as industrial accidents. The blame-shifting rationale, however, also seems wanting. First, there were no unambiguous gains to the state from pursuing such a strategy. That is, even if political leaders wanted to dodge blame by making the industry responsible for its 
own affairs, this approach in no way ensured that the government would not be castigated for having delegated responsibility in the first place. If anything, the strategy deprived the political leadership of a means to shift blame in case of need. For instance, while Rosstroi existed, its head could be made the scapegoat for poor outcomes, and severely reprimanded, or even fired, to appease public outcries. But if the move was unlikely to serve much good in front of the domestic public, it was also too obscure a reform outside of Russia for credit claiming before an international audience.

The empirical record is, however, largely consistent with the argument that the Russian political leadership was attempting to compensate for the state's own regulatory incapacity by fostering an extrastate substitute to public agencies. In both public statements and private interviews, officials stressed that self-regulation was needed to alleviate the failings of the public bureaucracy. This emphasis on the imperative to correct intrastate deficiencies, as well as address the problem of corruption, was ubiquitous. ${ }^{17}$

"Until recently, the only source of new standards was the government itself. And it was always late in updating these standards," declared Nabiullina, the Minister of Economic Development and Trade, adding that "such delays not only hampered the development of new technologies, but were a frequent source of corruption" (State Duma of the Russian Federation 2008).

According to Nikolai Kutyin, head of the Federal Service for Ecological, Technological and Nuclear Supervision (Rostekhnadzor), SROs "solve the problem of developing the regulatory framework (standards, rules, etc.) ... and relieve specialists within agencies of the executive branch from performing functions which have a corruption component, such as monitoring and approval" (Kutyin 2009).

As such statements suggest, while the government sought to benefit from industry knowledge, the notion of technical expertise can capture only one element of the government's rationale for delegation. By itself, it yields only a partial understanding of the public sector deficiencies, such as corruption, which industry self-regulation was meant to address.

Self-regulation was seen as shrinking opportunities for corruption, as well as establishing a potential counterweight to the bureaucracy. "It is absurd to believe in the benevolent bureaucrat," said Aleksandre Pochinok, Deputy Chairman of the Federation Council's Commission on Housing Policy, Housing and Public Utilities. "We don't need monopolies, but we do need self-regulating organizations to consolidate into powerful structures that are capable of doing battle with the ministries, defend their views [and] prepare policy" (Pochinok 2010). In a similar vein, United Russia's Martin Shakkum, then Chairman of the Duma Committee on Construction and Land Relations, underscored that "the transition to self-regulation consists not only of construction firms monitoring themselves.... [S]elf-regulating organizations can become the 'locomotives for systemic transformation' " (Sokolova 2009).

Correctly or not, the government considered it more viable to change the incentives facing the private sector rather than those of the public servants on its own payroll. Proponents of self-regulation argued that the mechanism of a pooled compensation fund would engender "elbow responsibility" and induce companies to vigilantly monitor each other, and punish misconduct. As noted by one official, "a bureaucrat's sense of responsibility is circumscribed solely by his salary, since administrative and criminal sanctions are practically unattainable. By contrast, self-regulation rests on a community of professionals ... who assume collective financial responsibility" for each other (Zaslavskaya 2010). Officials also believed that firms would choose to join reputable SROs that could confer "reputational benefits." Moreover, firms were 
expected to come to value membership because of the greater institutionalized access to policymaking promised to SROs. ${ }^{18}$

The government's lack of faith in the capacity of its own public servants helps makes sense of why industry self-regulation was chosen over more traditional, less experimental, policy instruments-such as reforming licensing requirements or adding staff to existing agencies to intensify monitoring-for addressing issues of quality and safety in the construction sector. The abolition, rather than reform, of Rosstroi is also highly suggestive in this regard.

\section{Conclusion}

Why might governments devolve regulatory powers to the private sector? The concept of substitutional delegation suggests that they do so to circumvent a corrupt and ineffective state bureaucracy. The article demonstrated that the government's ambitious agenda to (literally) build a new Russia created a fundamental mismatch between the needs of the state and the behavior of its public agents. Rather than continue with the Sisyphean task of reforming a recalcitrant bureaucracy, the political leadership opted for an alternative: The state actively sought to create new private agents who could substitute for malfunctioning state agencies.

In this respect, Russia may well be representative of other developing states that find themselves institutionally ill-equipped for carrying out the array of tasks confronted by political leaders. Many governments, from Beijing to Caracas, can successfully manipulate the political arena, but are unable to secure compliance with their directives down the length of the entire bureaucratic hierarchy. While there are numerous political and economic reasons why political authorities may be unable or unwilling to overhaul the entire administrative apparatus and comprehensively tackle the problem of corruption, the imperative to enhance the governance of particular economic sectors, especially when these become politically important, can drive the search for new regulatory strategies that bypass existing state agencies.

The argument thus speaks to the literature on state capacity that figures prominently in political science. Growing concern over the stark capacity deficits that hamper effective governance around the world has brought forth an ambitious research agenda that seeks to understand both the constitutive elements of state capacity and the causal forces that enable governments to develop and enhance their powers to perform necessary tasks. Much of this research has been oriented toward investigating how governments build up the intrastate structures, particularly the bureaucracies, that enable governance. At the same time, it has also been theoretically recognized that the capacity to govern can derive from the extent to which states are embedded in society (Evans 1995; Mann 1993; Midgal 2001; Soifer and vom Hau 2008). The scholarship on developmental associations, in particular, emphasizes that closer ties to industry can enhance the state's ability to implement policies (Doner and Schneider 2000; Maxfield and Schneider 1997). Adding to this latter line of inquiry, this study showed why state authorities delegated regulatory power to industry instead of making further investments in reforming the state apparatus. But rather than focus on state efforts to work with existing associations, as previous studies have done, the article demonstrated that the government itself spurs the formation of de novo groups to act as operational substitutes for underperforming public agencies.

While focusing on government imperatives, the article also suggested reasons why Russian constructions firms resisted the shift to private governance. Corruption in the public sector appeared to factor into firms' calculations of whether or not to support 
industry self-regulation. When the "shadow of hierarchy" — the Damocles' sword of direct government intervention-can be attenuated through resort to informal ties, as well as outright bribes, there are fewer incentives for firms to embrace private governance over continued regulation by corruptible regulators. In this respect, the argument may contribute to extant debates about the conditions that support or hinder private governance. The argument implies that the clarity and content of preferences for or against industry self-regulation, on the part of both political authorities and private actors, are likely contingent on the degree of subversion of existing public institutions.

This study underscores the need for further empirical and theoretical work on delegation and private governance in countries where the state's regulatory capacity is weak. One limitation of the present study has been its focus on the construction sector in Russia. Future cross-national or cross-sectoral studies can shed further light on the hypothesized importance of the government's pro-active role in fostering industry self-regulation, as well as the degree to which preexisting relationships between firms and regulators condition private sector preferences for private governance relative to hierarchical steering by government. Another fruitful avenue may be the study of the relative effectiveness of industry self-regulation in such settings. While this article has argued that self-regulation regimes warrant more attention as potential regulatory mechanisms that governments may seek when public institutions have been subverted, the present analysis is ultimately agnostic as to the prospects of success when self-regulation is imposed from on high, rather than preemptively or voluntarily undertaken by industry. More research is warranted before the matter can be settled empirically.

\section{Acknowledgments}

I am grateful to Timothy Colton, Peter Hall, Ulrich Krotz, Steven Levitsky, Elina Treyger, the editors of Governance, and three anonymous reviewers for their very helpful comments on this manuscript. Much gratitude to Adrienne Héritier and Brigid Laffan for their support and mentorship at the Robert Schuman Centre for Advanced Studies. I also wish to thank the participants of workshops convened at the Minda de Gunzburg Center for European Studies (Harvard University), the Davis Center for Russian and Eurasian Studies (Harvard University), the Institute of Humane Studies, and the European University Institute, for their input and encouragement in the early stages of this study.

\section{Notes}

1. Industry self-regulation is defined here as "a regulatory process whereby an industrylevel, as opposed to a governmental- or firm-level, organization sets and enforces rules and standards relating to the conduct of firms in the industry" (Gupta and Lad 1983, 417).

2. Fieldwork for this article included 37 semistructured interviews with the owners and/or senior management of 17 construction-sector firms operating in Moscow and St. Petersburg, staff members of 6 business associations who could speak with authority about the industry, and 14 government officials from the Russian executive and legislative branches with direct knowledge of, or participation in, the development of the SRO framework. All interviews were conducted in Russian by the author. Most interviews were conducted in confidentiality, and the names of the interviewees are withheld by mutual agreement.

3. Policy complexity as a reason for delegation also features prominently within the literature on delegation between the legislative and executive branches and/or independent (or 
quasi-independent) public agencies (see Bawn 1995; Bendor, Glazer, and Hammond 2001; Carpenter 2001; Epstein and O'Halloran 1999; Huber and Shipan 2006; McCubbins and Page 1991).

4. Huber and McCarty (2004) similarly distinguish the problem of information from the problem of capacity. They focus, however, on delegation within the public bureaucracy. By contrast, this study considers delegation to private agents.

5. To the extent that this argument depicts bureaucratic corruption as a hindrance to political leaders, it runs counter to views of corruption as a tool enhancing the state principal's administrative control (see, e.g., Darden 2008; Waterbury 1973). In this view, in addition to serving as an (unofficial) second salary that helps incentivize underpaid public servants, graft also enables leaders to exert pressure on subordinates. By first tolerating (or even encouraging) bribe taking by public officials, but later threatening them with exposure and punishment, political principals can "secure the loyalty and obedience of officials within the state's administrative hierarchies" (Darden 2008, 37). While acknowledging the efficacy of blackmail for enforcing political loyalty, I question the analytical utility of conflating political quiescence with administrative compliance. Empirically, the two frequently do not go together. As Huskey (2012) notes with respect to Russia: "Although those in state service serve as loyal agents of political principals on matters of high importance to their superiors, such as re-election campaigns, they often pursue their own agendas as independent actors on many everyday matters of administration. The result is a plethora of informal practices that often undermine official policies of the state" (176). Moreover, since blackmail "requires a robust surveillance apparatus to be effective" (Darden 2008, 43), this tool likely loses its effectiveness as one moves down the bureaucratic hierarchy from top bureaucrats (e.g., ministers) to street-level inspectors. While the behavior of the former may be monitored, the conduct of the much more numerous latter is likely to evade notice, and thus control.

6. On the importance of institutional design, see Gunningham and Rees (1997).

7. Author's interview with an official with ties to the presidential administration, Moscow, October 2008.

8. Russian governance under Putin has at times been described as "a dictatorship of incompetence" (Inozemtsev 2011) and "authoritarianism without authority" (Stoner-Weiss 2006).

9. Author's interview with an advisor to the president's Anti-Corruption Council, Moscow, December 2008.

10. Ministry of Regional Development Order 274 (issued December 9, 2008) detailed the activities to be certified by SROs. Construction companies operating without being admitted to an SRO were subject to administrative and criminal liability.

11. Author's interviews, Moscow, November 2008, and St. Petersburg, December 2008.

12. Author's interview, Moscow, October 2008.

13. Author's interviews, Moscow, November 2008 and June 2010.

14. Author's interview, Moscow, November 2008.

15. See Hanson and Teague (2005) for a discussion of the subordinate place of business in the Russian political system.

16. Author's interview with a deputy of the Federal Licensing Center, Moscow, September 2008. See also Marina Gritsiuk, “Daesh litsenziu," Rossiiskaia Gazeta, October 24, 2007, 3.

17. Author's interviews with officials at Rostekhnadzor and the Ministry of Economic Development and Trade, Moscow, June 2010.

18. Author's interviews with a representative from the State Duma's Committee on Construction and Land Relations, Moscow, June 2010.

\section{References}

Bawn, Kathleen. 1995. "Political Control versus Expertise: Congressional Choices about Administrative Procedures." American Political Science Review 89 (1): 62-73.

Becker, Gary. 1983. "A Theory of Competition among Pressure Groups for Political Influence." Quarterly Journal of Economics 98 (August): 371-400.

Bendor, Jonathan, Amihai Glazer, and Thomas Hammond. 2001. "Theories of Delegation." Annual Review of Political Science 4 (1): 235-269.

Bryanskii, Alexei. 2007. "Росстрой хочет продлитъ лицензирование строительной деятельности" [Rosstroi Calls for Extending Licensing in Construction]. Томский Вестник [Tomsk Herald] (February 2): 5. 
Carpenter, Daniel P. 2001. The Forging of Bureaucratic Autonomy: Reputations, Networks, and Policy Innovation in Executive Agencies, 1862-1928. Princeton, NJ: Princeton University Press.

Darden, Keith. 2008. "The Integrity of Corrupt States: Graft as an Informal State Institution." Politics E Society 36 (1): 35-59.

Demski, Joel S., David Sappington, and Pablo Spiller. 1987. "Managing Supplier Switching." Rand Journal of Economics 18 (1): 77-97.

Doner, Richard F. 1992. "Limits of State Strength: Toward an Institutionalist View of Economic Development." World Politics 44 (3): 398-431.

Doner, Richard F., and Ben Ross Schneider. 2000. "Business Associations and Economic Development: Why Some Associations Contribute More Than Others." Business and Politics 2 (3): 261-288.

Epstein, David, and Sharyn O'Halloran. 1995. "A Theory of Strategic Oversight: Congress, Lobbyists, and the Bureaucracy." Journal of Law, Economics \& Organization 11 (2): 227-255.

- 1996. "Divided Government and the Design of Administrative Procedure: A Formal Model and Empirical Test." Journal of Politics 58 (2): 373-397.

- 1999. Delegating Powers: A Transaction Cost Politics Approach to Policy Making under Separate Powers. Cambridge, UK: Cambridge University Press.

Evans, Peter. 1995. Embedded Autonomy: States and Industrial Transformation. Princeton, NJ: Princeton University Press.

Fiorina, Morris P. 1982. "Legislative Choice of Regulatory Forms: Legal Process or Administrative Process?" Public Choice 39 (1): 33-66.

Frye, Timothy. 2000. Brokers and Bureaucrats: Building Market Institutions in Russia. Ann Arbor, MI: University of Michigan Press.

Grajzl, Peter, and Peter Murrell. 2007. “Allocating Lawmaking Powers: Self-regulation vs Government Regulation." Journal of Comparative Economics 35 (3): 520-545.

Gunningham, Neil, and Joseph Rees. 1997. "Industry Self Regulation: An Institutional Perspective." Law and Policy 19 (4): 363-414.

Gupta, Anil, and Lawrence J. Lad. 1983. "Industry Self-Regulation: An Economic, Organizational, and Political Analysis." Academy of Management Review 8 (3): 416-425.

Halfteck, Guy. 2008. "Legislative Threats." Stanford Law Review 61 (3): 629-710.

Hanson, Philip, and Elizabeth Teague. 2005. "Big Business and the State in Russia." Europe-Asia Studies 57 (5): 657-680.

Héritier, Adrienne. 2003. "New Modes of Governance in Europe: Increasing Political Capacity and Policy Effectiveness?" In The State of the European Union, ed. Börzel Tanja and Rachel Chichowski. Oxford: Oxford University Press.

Héritier, Adrienne, and Sandra Eckert. 2008. "New Modes of Governance in the Shadow of Hierarchy: Self-Regulation by Industry in Europe." Journal of Public Policy 28 (1): 113138.

Herszenhorn, David M. 2014. “Olympics Opening Ceremony Offers Fanfare for a Reinvented Russia." New York Times, February 7.

Hopenhayn, Hugo, and Suzanne Lohmann. 1996. "Fire-Alarm Signals and the Political Oversight of Regulatory Agencies." Journal of Law, Economics, and Organization 12 (1): 196-213.

Huber, John, and Nolan McCarty. 2004. "Bureaucratic Capacity, Delegation, and Political Reform." American Political Science Review 98 (3): 481-494.

Huber, John, and Charles R. Shipan. 2006. "Politics, Delegation, and Bureaucracy." In The Oxford Handbook of Political Economy, ed. Barry Weingast and Donald Wittman. Oxford: Oxford University Press.

Huskey, Eugene. 2012. "The Bureaucracy." In Routledge Handbook of Russian Politics and Society, ed. Graeme Gill and James Young. New York: Routledge.

Inozemtsev, Vladislav. 2011. "Neo-Feudalism Explained." American Interest 6 (4): 73-80.

Kay, John. 1988. “The Forms of Regulation." In Financial Regulation—or Over-Regulation, ed. Seldon Arthur. London: Institute of Economic Affairs.

Kutyin, Nikolai. 2009. “Саморегулирование поможет избавиться от коррупции” [Self-Regulation Will Help Eliminate Corruption]. Russian Business Newspaper 709 (July 7):25.

Lewis, David. 2003. Presidents and the Politics of Agency Design: Political Insulation in the United States Government Bureaucracy, 1946-1997. Stanford, CA: Stanford University Press.

Lucas, John. 1997. "The Politics of Business Associations in the Developing World." Journal of Developing Areas 32 (1): 71-96.

McCubbins, Matthew, and Talbot Page. 1991. "A Theory of Congressional Delegation." In Congress: Structure and Policy, ed. Matthew McCubbins and Terry Sullivan. Cambridge, UK: Cambridge University Press. 
McCubbins, Matthew, and Thomas Schwartz. 1984. “Congressional Oversight Overlooked: Police Patrols versus Fire Alarms." American Journal of Political Science 28 (1): 165-179.

Mann, Michael. 1993. The Sources of Social Power, Vol. 2. New York: Cambridge University Press. Markus, Stanislav. 2007. "Capitalists of All Russia, Unite! Business Mobilization under Debilitated Dirigisme." Polity 39 (3): 277-304.

Mattli, Walter, and Tim Büthe. 2005. "Accountability in Accounting? The Politics of Private Rule-Making in the Public Interest." Governance 18 (3): 399-429.

Maxfield, Sylvia, and Ben Ross Schneider. 1997. Business and the State in Developing Countries. Ithaca, NY: Cornell University Press.

Maxwell, John, Thomas P. Lyon, and Steven Hackett. 2000. "Self-Regulation and Social Welfare: The Political Economy of Corporate Environmentalism." Journal of Law and Economics 43 (2): 583-617.

Midgal, Joel. 2001. State in Society: Studying How States and Societies Transform and Constitute One Another. New York: Cambridge University Press.

Milov, Vladimir, Boris Nemtsov, Vladimir Ryzhkov, and Olga Shorina, ed. 2011. Putin. Korruptsiya. Nezavisimi Expertni Doklad. Moscow: La Russophobe.

Monaghan, Andrew. 2012. "The Vertikal: Power and Authority in Russia." International Affairs 88 (1): 1-16.

Nalebuff, Barry J., and Joseph Stiglitz. 1983. "Information, Competition, and Markets." The American Economic Review 73 (2): 278-283.

Ogus, Anthony. 1999. "Self-Regulation." In Encyclopedia of Law and Economics, ed. Bouckaert Boudewijn and Gerrit De Geest. Cheltenham: Edward Elgar.

PMR Publications. 2010. Construction Sector in Russia, 2010.

Pochinok, Aleksandre. 2010. "Я сторонник обязательного саморегулирования." [I Am a Supporter of Mandatory Self-regulation]. Zakon 2 (February): 242-246.

Posner, Richard. 1974. "Theories of Economic Regulation." Bell Journal of Economics and Management Science 5 (Autumn): 335-358.

RIA Novosti. 2008. "Putin Calls Housing Construction in Russia a Strategic State Objective." September 23.

- 2010. "Medvedev Warns Bureaucrats Against Putting Off His Orders." March 16.

Sakwa, Richard. 2010. The Crisis of Russian Democracy: The Dual State, Factionalism and the Medvedev Succession. Cambridge, UK: Cambridge University Press.

Sappington, David. 1991. "Incentives in Principal-Agent Relationships." Journal of Economic Perspectives 5 (2): 45-66.

Schneider, Ben Ross, and Blanca Heredia, ed. 2003. Reinventing Leviathan: The Politics of Administrative Reform in Developing Countries. Miami, FL: North-South Center Press.

Segerson, Kathleen, and Thomas Miceli. 1998. "Voluntary Environmental Agreements: Good or Bad News for Environmental Protection?" Journal of Environmental Economics and Management 36 (2): 109-130.

Shane, Scott, and Andrew W. Lehren. 2010. "Leaked Cables Offer Raw Look at U.S. Diplomacy." The New York Times (November 29): A1.

Smolchenko, Anna. 2009. “Dam Tragedy Shows Russia Lags Behind: President.” Agence France Presse, August 24.

Soifer, Hillel, and Matthias vom Hau. 2008. "Unpacking the Strength of the State: The Utility of State Infrastructural Power." Studies in Comparative International Development 43 (3): 219-230.

Sokolova, Maria. 2008. "От госконтроля к саморегулированию рынка" [From State Control to the Self-Regulating Market]. Parlamentskaia Gazeta 34: 14. May 22.

—. 2009. “Строителъство переходит на самоконтролъ." [Construction Transitions to SelfControl]. Parlamentskaia Gazeta 61: 7. November 17.

Stefanadis, C. 2003. "Self-regulation, Innovation, and the Financial Industry." Journal of Regulatory Economics 23 (1): 5-25.

Stigler, George J. 1971. "The Theory of Economic Regulation." Bell Journal of Economics 2 (1): 3-21.

Stoner-Weiss, Kathryn. 2006. Resisting the State: Reform and Retrenchment in Post-Soviet Russia. New York: Cambridge University Press.

Stroitel'naya Gazeta. 2008. “Открытое писъмо Президенту России” [Open Letter to the President of Russia]. (November 21): 2.

Tofanuk, Elena. 2004. "Россиянам угрожают опасные стройки" [Hazardous Construction Threatens Russia]. RBC Daily. June 2. <http:/ / www.rbcdaily.ru/market/562949979067974>

Trebilcock, Michael J. 1983. "Regulating Service Quality in Professional Markets." In The Regulation of Quality, ed. Donald N. Dewees. London: Butterworths. 
Waterbury, John. 1973. "Endemic and Planned Corruption in a Monarchical Regime." World Politics 25 (4): 533-555.

White, Stephen. 1986. "Economic Performance and Communist Legitimacy." World Politics 38 (3): 462-482.

Yakovlev, Evgeny, and Ekaterina Zhuravskaya. 2008. “Reforms in Business Regulation: Evidence from Russia." CEPR Discussion Paper No. 6610. <www.cepr.org/pubs/dps/DP6610.asp?> (accessed July 21, 2010).

Zaslavskaya, Olga. 2010. “Саморегулирование в строителъстве” [Self-Regulation in Construction]. Russian Business Newspaper 744 (April 6): 11. 